DOI: $\underline{\text { https://doi.org/10.24127/ajpm.v10i1.3379 }}$

\title{
EFFECTIVENESS OF SCHEMATIC REPRESENTATION IN SOLVING WORD PROBLEM
}

\author{
Rahmad Bustanul Anwar ${ }^{1 *}$, Dwi Rahmawati ${ }^{2}$, Sri Endang Supriyatun ${ }^{3}$ \\ ${ }^{1 *, 2}$ Pendidikan Matematika, Universitas Muhammadiyah Metro, Metro, Indonesia \\ ${ }^{3}$ SMP Negeri 4 Metro, Metro, Indonesia \\ * Corresponding author. Jl. Ki hajar Dewantara No. 116 Iringmulyo, Kota Metro, Lampung \\ E-mail: $\quad$ rarachmadia@gmail.com ${ }^{1 *}$ \\ dwirahmawati1083@gmail.com $^{2)}$ \\ sriendank@gmail.com ${ }^{3)}$
}

Received 11 December 2020; Received in revised form 17 February 2021; Accepted 29 March 2021

\begin{abstract}
Schematic representation is very important for students to solve problems in solving word problems. There are two types of schematic representation namely pure schematic representation and mixed schematic representation. The process of forming a pure schematic representation tends to be more concise than the process of forming a mixed schematic representation. So it is necessary to investigate in more detail and in-depth which is more effective between pure schematic representation or mixed schematic representation in helping students to solve word problems. This study aims to determine the effectiveness of pure schematic representation and mixed schematic representation in solving word problems. The effectiveness mentioned in this study is the accuracy and precision of the schematic representation formed by the students when solving word problems. This study uses a qualitative approach involving students from grade IX in Metro City, Lampung, Inonesia as research subjects. The students involved in this study were 60 students. Of the 60 students, two were selected as research subjects representing pure schematic representation and mixed schematic representation. Both subjects were chosen considering the possibility of forming a schematic representation and having good communication skills. The results of this study indicate that students who form pure schematic representation present information and schematic drawings formed in a more concise, precise and accurate manner. While students who form a mixed schematic representation by presenting less structured information, the schematic drawings formed are longer. So it can be concluded that a pure schematic representation is more effective than a mixed schematic representation for solving word problems.
\end{abstract}

Keywords: Representations; mixed schematic representations; pure schematic representations; word problem.

\begin{abstract}
Abstrak
Representasi skematis sangat penting bagi siswa untuk mengurai masalah dalam menyelesaikan word problem. Terdapat dua jenis representasi skematis yaitu representasi skematis murni dan representasi skematis campuran. Proses terbentuknya representasi skematis murni cenderung lebih ringkas (pendek) dibandingkan dengan proses terbentuknya representasi skematis campuran. Maka perlu diselidiki lebih detail dan mendalam manakah yang lebih efektif antara representasi skematis murni atau representasi skematis campuran dalam membantu siswa selama menyelesaikan word problem. Penelitian ini bertujuan untuk mengetahui efektivitas antara representasi skematis murni dan representasi skematis campuran dalam pemecahan word problem. Efektivitas yang dimaksud dalam penelitian ini adalah ketepatan dan keakuratan representasi skematis yang dibentuk siswa selama menyelesaikan word problem. Penelitian ini menggunakan pendekatan kualitiatif yang melibatkan siswa kelas IX di Kota Metro, Lampung, Indonesia sebagai subjek penelitian. Siswa yang terlibat dalam penelitian ini berjumlah 60 siswa. Dari 60 siswa dipilih dua siswa sebagai subjek penelitian yang mewakili representasi skematis murni dan representasi skematis campuran. Dua subjek tersebut dipilih melalui pertimbangan mampu membentuk representasi skematis dengan baik, dan memiliki kemampuan komunikasi yang baik. Sebuah tes diberikan untuk mengetahui kemampuan siswa dalam membentuk representasi skematis. Hasil pekerjaan siswa yang terkumpul dianalisis dan digunakan sebagai bahan dalam wawancara untuk
\end{abstract}


DOI: https://doi.org/10.24127/ajpm.v10i1.3379

menggali informasi bagaimana siswa membentuk representasi skematis. Hasil penelitian ini menunjukkan bahwa siswa yang membentuk representasi skematis murni menyajikan informasi-informasi dan gambar skema yang dibentuk lebih ringkas, tepat dan akurat. Sedangkan siswa yang membentuk reprsentasi skematis campuran dalam menyajikan informasi-informasi kurang terstruktur, dan gambar skema yang dibentuk lebih panjang. Sehingga dapat disimpulkan bahwa representasi skematis murni lebih efektif daripada representasi skematis campuran selama menyelesaikan word problem.

Kata kunci: Representasi; representasi skematis campuran; representasi skematis murni; word problem.

This is an open access article under the Creative Commons Attribution 4.0 International License

\section{INTRODUCTION}

Representation is one of the important topics in learning mathematics, because, using representation, students can form mathematical ideas to be more concrete (National Council of Teachers of Mathematics, 2000). It also plays a role in strengthening students' understanding to build concepts and solve mathematical problems, especially word problems (Stylianou, 2010). The findings in several studies show that representation is an important part of mathematical activity (Nizarudin, 2014).

In general, representation can be interpreted as a configuration that can describe something differently. In the mathematical domain, representations are seen as internal abstractions of mathematical ideas or cognitive schemes developed by students through learning experiences (Pape \& Tchoshanov, 2001). One type of representation is schematic representation (Anwar et al., 2017; Fagnant \& Vlassis, 2013; Zahner \& Corter, 2010). Schematic representation is a representation that describes the relationship that explains the situation in the problem (Zahner \& Corter, 2010). Meanwhile, according to Zahner and Corter (2010), schematic representation is an activity of issuing important data about problems and relationships between them. Boonen et al. (2014) states that a visual representation is expressed as an accurate schematic representation if students can draw drawings or diagrams and use gestures or present a specific mental image that contains an appropriate relationship among the elements of the relevant solution to a problem. Then, it can be concluded that the schematic representation is a representation that contains the relationship of the information elements contained in the problem that can be realized with the form of the structure of Anwar (2018).

Several research results indicate that schematic representation helps students in the process of solving problems in the form of word problems (Anwar, et al., 2019; Boonen et al., 2014; Fagnant \& Vlassis, 2013. According to Fagnant \& Vlassis (2013), schematic representation is a very important tool for solving complex problems because students can illustrate the content of problems in a schematic way. Hegarty and Kozhevnikov (1999) claim that by using a schematic representation, students can emit primary data and discover the relationships between the information presented in the problem. Therefore, they should be encouraged to form a schematic representation in the presentation of relationships between various elements of the problem, in order to obtain the right solution (Thevenot \& Barrouillet, 2015).

The research by Boonen et al. (2014) found two types of schematic representations, namely, accurate 
schematic and inaccurate schematic representation. Accurate schematic representation can increase success in solving problems, because students can connect elements of relevant solutions and integrate them into coherent visualizations of problem situations. In the inaccurate visual schematic representation there is an error in the drawing or a missing part, resulting in the student's failure to solve the problem. Anwar et al. (2017) continued the research by Boonen et al. (2014), who focused on the type of accurate schematic representation. From this study, he classifies the schematic representation in two, namely, pure schematic representation and mixed schematic representation. The pure schematic representation is shown in the form of schematic drawings equipped with information that corresponds to the problem information. The mixed schematic representation is manifested in the form of schematic drawings, complemented by real information and images of (pictorial) objects that correspond to the problem information.

Based on the results of the research Anwar et al. (2017), show that both pure schematic and mixed schematic representation strongly support students' success in solving mathematical problems of words. But, it is still very necessary to see the effectiveness between pure schematic representation and mixed schematic representation. This needs to be researched because seeing the level of effectiveness will help mathematics teachers in providing alternatives in solving mathematical problems, especially word problems. The level of effectiveness in question is the accuracy and accuracy of schematic representations formed by students during solving word problems, because by forming and using schematic representations that are effective in solving problems will display all the information understood by students and know the strategy chosen when solving the problem.

\section{METHODS}

This type of research is qualitative and descriptive. This was chosen because the data in this study were in the form of descriptions of the results of the students' work as outlined on a sheet of paper which was equipped with information from students obtained through interviews. These data are used to compare of effective pure schematic representation and mixed representation formed in problem solving process by students. The participants in this study were 60 students from class IX in Metro City. This research begins by asking students to solve a problem using paper and pencil. The results of the collected students' work are analyzed and used as material in conducting interviews. This interview is used to gain more in-depth information about how students form a schematic representation while solving problems. Based on the results of the work and the interview, two students were chosen as representatives of subjects representing pure schematic representation and subjects with mixed schematic representation. These two subjects were chosen with the consideration of able to form a schematic representation, providing written information in full, having a different "unique" way of responding to problems and having good communication skills. To help collect data on the formation of schematic representations, the researchers used Polya's problem-solving stage indicators developed by Anwar (2018), which are presented in Table 1. 
DOI: https://doi.org/10.24127/ajpm.v10i1.3379

Table1. Indicators of Forming Schematic Representation in Problem Solving

\begin{tabular}{|c|c|c|}
\hline Category & Description & Student Activities Based on Problem Solving Stages \\
\hline $\begin{array}{l}\text { Pure } \\
\text { schematic } \\
\text { representation }\end{array}$ & $\begin{array}{l}\text { Students identify } \\
\text { problems by writing } \\
\text { down some important } \\
\text { information, forming a } \\
\text { schema linking some } \\
\text { identified information to } \\
\text { obtain alternative } \\
\text { solutions and making a } \\
\text { series of calculations to } \\
\text { solve the problem. }\end{array}$ & $\begin{array}{l}\text { 1. Understanding the problem } \\
\text { a. Read the problem repeatedly with full emphasis on } \\
\text { each sentence for information. } \\
\text { b. Identify the problem by writing down some important } \\
\text { information. } \\
\text { 2. Devising a plan } \\
\text { Form a scheme to find alternative solutions to } \\
\text { problems. } \\
\text { 3. Carrying out the plan } \\
\text { Perform a series of calculations based on your chosen } \\
\text { workaround. } \\
\text { 4. Looking back } \\
\text { a. Correcting the calculation that was done. } \\
\text { b. Write a conclusion based on the responses obtained. }\end{array}$ \\
\hline $\begin{array}{l}\text { Mixed } \\
\text { schematic } \\
\text { representation }\end{array}$ & $\begin{array}{l}\text { Students identify } \\
\text { problems by creating } \\
\text { schemas, connecting } \\
\text { some understood } \\
\text { information with images } \\
\text { of real objects that } \\
\text { correspond to the } \\
\text { problem information, } \\
\text { drawing schematic } \\
\text { drawings to obtain } \\
\text { alternative solutions and } \\
\text { making a series of } \\
\text { calculations to solve the } \\
\text { problem. }\end{array}$ & $\begin{array}{l}\text { 1. Understanding the problem } \\
\text { a. Read the problem repeatedly with full emphasis on } \\
\text { each sentence for information about the problem. } \\
\text { b. Decompose the problem by forming a schema, } \\
\text { linking identified information equipped with images } \\
\text { of real objects that correspond to the information in } \\
\text { the problem. } \\
\text { 2. Devising a plan } \\
\text { Look for schematic drawings for alternative solutions } \\
\text { to problems. } \\
\text { 3. Carrying out the plan } \\
\text { Perform a series of calculations based on your chosen } \\
\text { workaround. } \\
\text { 4. Looking back } \\
\text { a. Combining the information in the problem with the } \\
\text { schema formed. } \\
\text { b. Correcting the calculation that was done. } \\
\text { c. Write a conclusion based on the responses obtained. }\end{array}$ \\
\hline
\end{tabular}

There are two instruments used in this study, namely mathematical problems in the form of word problems and interview guides. The test uses a problem used to measure students' ability to form a schematic representation with a question related to the Pythagorean material. This problem was chosen with the consideration that it has been validated by three experts in the field of mathematics education and declared valid and suitable for use in data collection. The problem used was "Faiz used to visit Farhan's house walking south for 40 meters, then turning east for 30 meters and going south again for 32 meters. In addition to the road that Faiz used to visit Farhan's house, there are a shortcut across the garden between their houses. Today Faiz wants to take a shortcut in the garden to get to Farhan's house as soon as possible. How long is the shortcut between Faiz and Farhan's house?".

In addition, this study also used interview guidelines. General interview guidelines to reveal how students form schematic representations. Specifically, the interviews flowed based on the students' work results. There are four interrelated stages of solution, namely: understanding the problem, devising a plan, carrying out the plan and looking back. Based on the analysis at these stages, the subjects are grouped into two, namely students who form a pure 
schematic representation and a mixed schematic representation. Then, each problem solving is analyzed to verify the effectiveness of the schematic representation formed by the students.

\section{RESULTS AND DISCUSSION}

Based on the results of the research conducted, two subjects were selected to represent a pure schematic representation and a mixed schematic representation. The second subject is chosen because it can provide complete information during the process of forming a schematic representation. The following is a description of the process of forming a pure schematic representation and a mixed schematic representation:

\section{Subject 1 (S1): Pure Schematic Representation}

The S1 troubleshooting process begins with reading the problem repeatedly. After reading a problem, it seems that $\mathrm{S} 1$ was unable to understand the problem. To help understand the problem of $\mathrm{S} 1$ making doodles on a spreadsheet. The graphite made by $\mathrm{S} 1$ forms an outline or scheme [Tpm-1] that represents the content of the problem's history. The problem-solving process carried out by $\mathrm{S} 1$ is shown in the following excerpt of the interview between Researcher $(R)$ and Subject $(S)$ : $R$ : What information is in this issue?

S1: information goes 40 meters south then 30 meters east then 32 meters south again.

$R:$ What is 40 meters?

S1: the distance traveled by Faiz to the south then east to 30 meters, to the south again by 32 meters.

$R$ : oo... the distance Faiz traveled to Farhan's house?

S1: Yes, then between Faiz's house and Farhan's house there is a garden, there is a shortcut. Mean the garden here (pointing to the beveled and rectangular image)

$R:$ ok .. then the question of what is this problem?

S1: how long is the shortcut (pointing to the oblique side of the triangle), so from the end of this line to here.

$R$ : So, do you think the shortcut is this side?

S1: yes

In addition, $\mathrm{S} 1$ is associated with information about understanding the problem with the knowledge already possessed. S1 associates the content of the problem with the material of the Pythagorean theorem [Tpm-2]. Armed with this knowledge, the $\mathrm{S} 1$ is able to solve problems using the right path and getting the right results [Tpm-3]. This is also reinforced by statement $\mathrm{S} 1$ in the following passage from the interview:

R: How much distance does Faiz usually take?

S1: 102 meters

R: How about passing a shortcut?

S1: 78 meters

$R$ : Ok, do you think there are other shortcuts or not?

S1: Emmm ... nothing

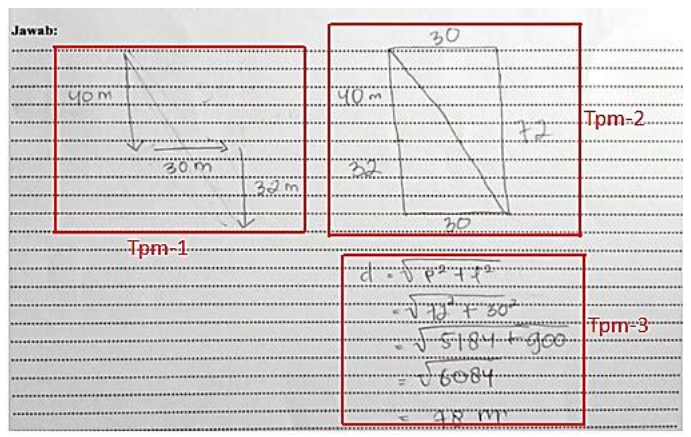

Figure 1. Subject 1 work results.

Based on the completion process and the results of the work shown in Figure 1, it shows that $\mathrm{S} 1$ is capable of forming a pure schematic representation 
well. The pure schematic representation $\mathrm{S} 1$ is formed in the process of understanding the problem. A pure schematic representation is formed by linking all the information obtained when reading a problem. The pure schematic representation is manifested in the form of sketches of the drawing of several lines equipped with distance information. Sketching the lines formed following the history of the problem.

\section{Subject 2 (S2): Mixed Schematic Representation}

The S2 troubleshooting process begins with reading the problem several times. S2 found it very difficult to understand the problem. S2 creates an image of the compass [Tpm-1.0] to help understand the content of the problem. The process of understanding the problems carried out by $\mathrm{S} 2$ is shown in the following passage from the interview:

$R:$ what information is in this problem? S2: On this matter, Faiz used to visit Farhan on foot. If using the normal road, He requires a distance of 102 meters and a longer time to get to Farhan's house. But besides the highway there is also a small road through the plantation to quickly arrive. $R:$ Is it already understood the contents of this problem?

S2: Um ... it's hard

$R$ : Why did you draw this compass?

S2: I'm having a hard time understanding this problem, so I drew a compass to understand it.

$R$ : Does drawing a compass help understand the problem?

S2: Yes the direction is clearer ... So I can understand.

The next S2 forms an outline of the problem in the form of a line figure equipped with a description of the distance and the name of the problem plot [Tpm-1.1]. The next S2 connects the problem to the concept of the Pythagorean theorem [Tpm-2.0]. With this process, $\mathrm{S} 2$ is able to simplify the problem, sketching the whole problem [Tpm-2.1] and performing calculations based on the chosen alternative [Tpm3], and S2 makes conclusions based on the questions of the problem [Tpm-4].

Based on the solution process and the answer S2 shown in Figure 2, it shows that $\mathrm{S} 2$ is able to form a mixed schematic representation during problem solving. The mixed schematic representation formed $\mathrm{S} 2$ in the process of understanding the problem. Schematic representation of the mixture is realized in the form of sketches of the drawings of several lines which are accompanied by captions and drawings of real objects.

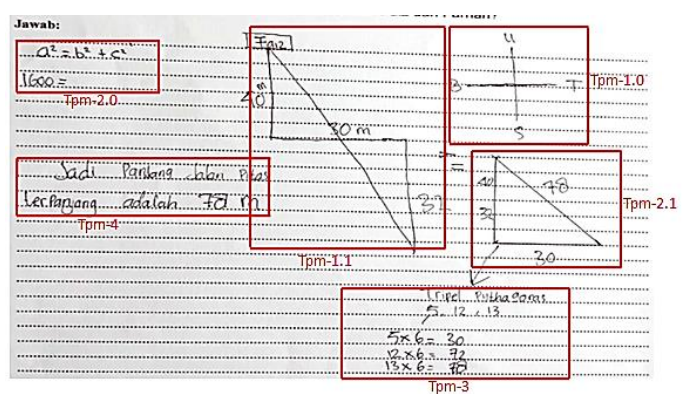

Figure 2. Subject work results 2

Based on the work of S1 and S2, the flowchart of schematic representation of the two subjects can be created while resolving the problem in Figure 3. Figure 3 shows the two processes of forming a schematic representation while solving a word problem. It appears that at the stage of understanding the problem, $\mathrm{S} 1$ is shorter in understanding the problem. This is consistent with what is shown in the work results of S1. By drawing a scheme (pure schematic representation), 
S1 can understand the problem well and succeed in solving the problem.

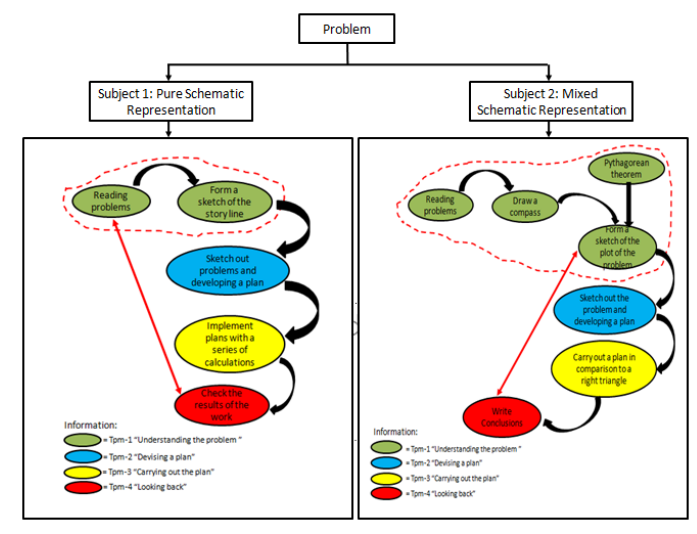

Figure 3. Schematic representation of both subjects in solving problems

This is in accordance with the statement of Stylianou (2010) which states that the scheme is a summary of information of the problem at hand. Forming a scheme will reduce the cognitive burden in storing information in students' minds. Whereas (Diezmann \& English, 2001) states that the process of understanding problems by forming schemes is one of the strategies that can be used in solving word problems, because using schemes can dismantle the structure of problems, simplify complex problems, and make abstract concepts more concrete. The results of this study also reviewed the results of Anwar's (2018) research that purely schematic representations were formed by students to understand information in a problem.

In the process of forming a schematic representation by S2 (Figure 3 ), it appears that S2 needs a longer process compared to $\mathrm{S} 1$ in understanding the problem. The problem solving process by $\mathrm{S} 2$ shows that $\mathrm{S} 2$ is very difficult in understanding problems. S2 must draw a compass to help understand the story line of the problem. With a compass tool, S2 can form a scheme (mixed schematic representation) to better understand the problem. Schematic drawing in the form of sketches of the main information that is equipped with drawings that match the information in the problem. By forming a mixed schematic representation, S2 is able to understand the problem and successfully solve the problem. This process is in accordance with the opinion of Sajadi et al. (2013) which states that in the reading process, students must communicate with verbal problems to understand the purpose of the problem. In addition by forming schematic drawings, they can have a cognitive structure that contains an organized plan for an activity and guide it in acting (VandenBos, 2015), as well as assist students in describing information and analyzing the relationships between information in a problem (Fennell \& Rowan, 2001). Students use compass images to help in form schemes. Students also draw a compass to follow the storyline presented in the problem. The use of real object images to complement the schematic drawings is reinforced by the opinion of the Anwar, et al., (2019) which states that the use of concrete images can help focus students' minds in detailing the main elements of the problem to represent the problem situation. So students can produce the right scheme. By forming schemes, they can understand information in a problem. This process is in accordance with the opinion (Broek et al., 2011) which states that to be able to truly understand the problem, students must create a coherent mental representation in an effort to present information.

\section{CONCLUSION AND SUGGESTION}

The results of this study indicate that the pure schematic representation 
formed by students can present all the information in the problem very briefly. In addition, the schematic drawings formed are more precise and accurate. Whereas the mixed schematic representation formed by students presents unstructured information and the schematic drawings formed are longer. This happens because students have difficulty understanding the information in the problem. Then it can be concluded that pure schematic representation is more effective than mixed schematic representation during solving word problems. Based on the results of this study, researchers provide suggestions for subsequent research in order to further research to prove whether the effectiveness of pure schematic representation in solving word problems is influenced by students' mathematical abilities.

\section{REFERENCES}

Anwar, R. B., Purwanto, As'ari, A. R., Sisworo, \& Rahmawati, D. (2019). The process of schematic representation in mathematical problem solving. IOP Conf. Series: Journal of Physics: Conf. Series 1157 (2019) 032075. https://iopscience.iop.org/article/ 10.1088/17426596/1157/3/032075

Anwar, R. B. (2018). Pembentukan Representasi Skematis dalam Menyelesaikan Masalah Matematis. Disertation, Universitas Negeri Malang, Malang. http://karyailmiah.um.ac.id/index.php/diserta si/article/view/76565

Anwar, R. B., Yuwono, I., As'ari, A. R., Sisworo, \& Rahmawati, D. (2017). Identifikasi Representasi Skematis dalam Menyelesaikan Masalah Matematika. Seminar
Nasional Pendidikan Matematika 2017, Malang. https://www.researchgate.net/publ ication/320696916_IDENTIFIKA SI_REPRESENTASI_SKEMATIS_ DALAM_MENYELESAIKAN_MA SALAH_MATEMATIKA

Boonen, A. J. H., van Wesel, F., Jolles, J., \& van der Schoot, M. (2014). The Role of Visual Representation Type, Spatial Ability, and Reading Comprehension in Word Problem Solving: An Item-Level Analysis in Elementary School Children. International Journal of Educational Research, 68, 15-26. https://doi.org/10.1016/j.ijer.2014 .08 .001

Broek, P. van den, Kendeou, P., Lousberg, S., \& Visser, G. (2011). Preparing for Reading Comprehension: Fostering Text Comprehension Skills in Preschool and Early Elementary School Children. International Electronic Journal of Elementary Education, 4(1), 259-268. https://www.iejee.com/index.php/I EJEE/article/view/223

Fagnant, A., \& Vlassis, J. (2013). Schematic Representations in Arithmetical Problem Solving: Analysis of Their Impact on Grade 4 Students. Educational Studies in Mathematics, 84(1), 149-168.

https://doi.org/10.1007/s10649013-9476-4

Fennell, F., \& Rowan, T. (2001). Representation: An Important Process for Teaching and Learning Mathematics. National Council of Teachers of Mathematics. http://link.galegroup.com/apps/do 
DOI: https://doi.org/10.24127/ajpm.v10i1.3379

c/A69796628/AONE?sid=googles cholar

Hegarty, M., \& Kozhevnikov, M. (1999). Types of Visual-Spatial Representations and Mathematical Problem Solving. Journal of Educational Psychology, 91(4), 684.

National Council of Teachers of Mathematics (Ed.), (2000). Principles and standards for school mathematics. National Council of Teachers of Mathematics, Reston, VA.

Nizarudin, (2014). Role of Multiple Representations in Mathematical Problem Solving. Presented at the International Conference on Mathematics, Science, and Education 20 14 (ICMSE 2014 ). http://icmseunnes.com/2015/wpcontent/uploads/2015/10/28.pdf

Pape, S.J., \& Tchoshanov, M.A., (2001). The Role of Representation(s) in Developing Mathematical Understanding. Theory Pract. 40, 118-27.

Sajadi, M., Amiripour, P., \& RostamyMalkhalifeh, M. (2013). The Examining Mathematical Word Problems Solving Ability under Efficient Representation Aspect. Mathematics Education Trends and Research, 2013. http://www.ispacs.com/journals/m etr/2013/metr-00007/abstract/
Stylianou, D. A. (2010). Teachers' Conceptions of Representation in Middle School Mathematics. Journal of Mathematics Teacher Education, 13(4), 325-343. https://doi.org/10.1007/s10857010-9143-y

Thevenot, C., \& Barrouillet, P. (2015). Arithmetic Word Problem Solving and Mental Representations. The Oxford Handbook of Numerical Cognition. https://doi.org/10.1093/oxfordhb/ 9780199642342.013.043

VandenBos, G. R. (Ed.). (2015). APA Dictionary of Psychology (2nd ed.). American Psychological Association. https://doi.org/10.1037/14646-000 Zahner, D., \& Corter, J.E., (2010). The Process of Probability Problem Solving: Use of External Visual Representations. Math. Think. Learn. 12, 177-204. https://doi.org/10.1080/10986061 003654240 